\title{
The Everglades Depth Estimation Network (EDEN) for Support of Ecological and Biological Assessments
}

\section{Introduction}

The Everglades Depth Estimation Network (EDEN) is an integrated network of real-time water-level monitoring, ground-elevation modeling, and water-surface modeling that provides scientists and managers with current (1999present), on-line water-depth information for the entire freshwater portion of the Greater Everglades. Presented on a 400-square-meter grid spacing, EDEN offers a consistent and documented dataset that can be used by scientists and managers to: (1) guide large-scale field operations, (2) integrate hydrologic and ecological responses, and (3) support biological and ecological assessments that measure ecosystem responses to the implementation of the Comprehensive Everglades Restoration Plan (CERP) (U.S. Army Corps of Engineers, 1999). The target users are biologists and ecologists examining trophic level responses to hydrodynamic changes in the Everglades.

\section{Approach}

Water depth is the difference between the water-surface elevation and the ground-surface elevation (fig. 1). To estimate water depths in the Greater Everglades, Geographical Information Systems (GIS) models were developed to determine the groundsurface and water-surface elevations for the freshwater portion of the Greater Everglades. Data to support the ground-elevation model include elevation measurements obtained at more than 50,000 sites (Desmond, 2003). Data to support the water-surface model include continuous water-level mea- surements obtained at more than 250 sites. Technical aspects of the EDEN monitoring network and GIS models are presented in the subsequent sections.

\section{Monitoring Network}

The EDEN monitoring network includes ground-elevation measurements and continuous water-level data. GroundU.S. Geological Survey (USGS; Desmond, 2003) at more than 50,000 points with an approximate spacing of 400 meters covering almost the entire Greater Everglades.

The EDEN water-level network consists of hourly water-level data from 253 gaging stations (230 existing gaging stations and 23 new installations) and includes freshwater (nontidal) marsh gaging stations, boundary gages on canals, and coastal (tidal) gages operated by the Big Cypress National Preserve (BCNP), Everglades National Park (ENP), South Florida Water Management District (SFWMD), and USGS (fig. 2). All gaging stations have telemetry equipment that provides data on a daily basis. Several of the new gaging surface elevation data were collected by the

stations are co-located where ongoing landscape studies have been conducted for several years. A 6-year (October 1, 1999, to September 30, 2005) dataset of baseline conditions was established for the EDEN water-level network prior to the implementation of CERP, offering scientists a single repository for historic, hourly water-level data.

Development of a water surface across the Everglades requires a consistent datum. Highly accurate ground-elevation data were collected using the North American Vertical Datum of 1988 (NAVD 88). Water-level gaging stations have been surveyed, until recently, to the National Geodetic Vertical Datum of 1929 (NGVD 29); however, this datum has inconsistencies in the vertical network that have never been resolved for southern Florida. The NAVD 88 datum is consistent in comparing water-level data across the Greater Everglades and computing accurate water depths.

The U.S. Army Corps of Engineers (USACE) and SFWMD recently documented or surveyed a majority of the hydrologic gages in the Greater Everglades to obtain correct values for converting water-level data from NGVD 29 to

NAVD 88. These and other data provided by BCNP and ENP have been used to create datum-correction values for the EDEN network gages, allowing historic water-level data to be converted from NGVD 29 to NAVD 88. Three methods were used to determine the correction for a gaging station:

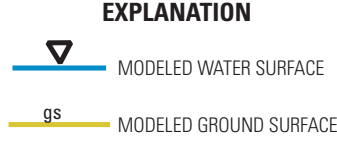

Figure 1. Relation between the modeled surfaces. Modeled water-surface elevation minus modeled ground-surface elevation is the water depth at any point in time. Water depth may be adjusted by the ground surface as a result of the relation between vegetation in the cell and ground elevation.
1. Differential or basic Global Positioning System (GPS) - A highly accurate satellite-based surveying system; 


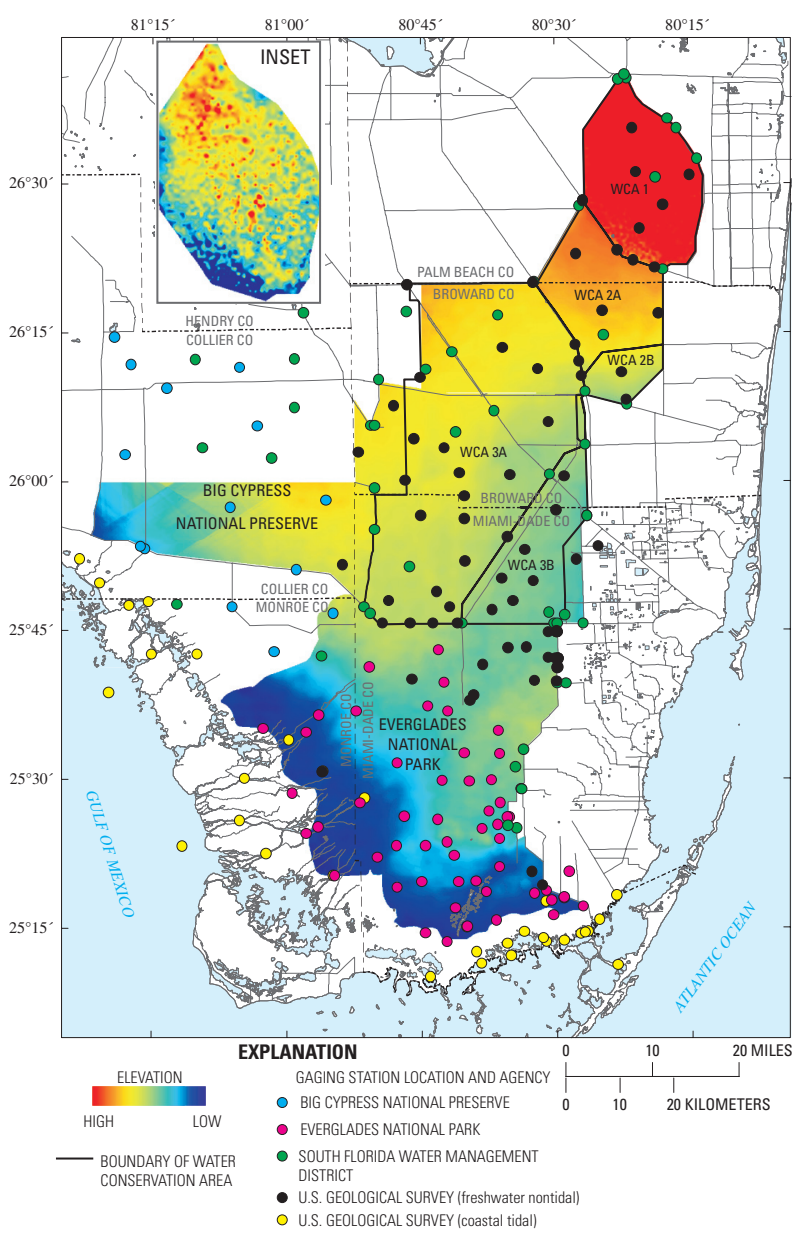

Figure 2. Location of Everglades Depth Estimation Network (EDEN) gaging stations in southern Florida and the EDEN region ground-elevation model (excluding coastal areas) created by joining water-conservation areas (WCAs), Everglades National Park, and portions of Big Cypress National Preserve elevation models. Inset is detailed ground-water elevation data for WCA 1.

2. Optical survey - A traditional lineof-sight survey from points of known elevation; and

3. CORPSCON ${ }^{1}$ version 6.0 - A program that interpolate the difference between ground elevation in NAVD 88 and NGVD 29 for a given location specified by latitude and longitude, and further refined by using the VERTCON version 2.5 grid modified by the USACE Jacksonville District to incorporate the CERP vertical control network established in 2001-02 (Rory Sutton, U.S. Army Corps of Engineers, written commun., 2005).

\footnotetext{
${ }^{1}$ Any use of trade, product, or firm names is for descriptive purposes only and does not imply endorsement by the U.S. Government.
}

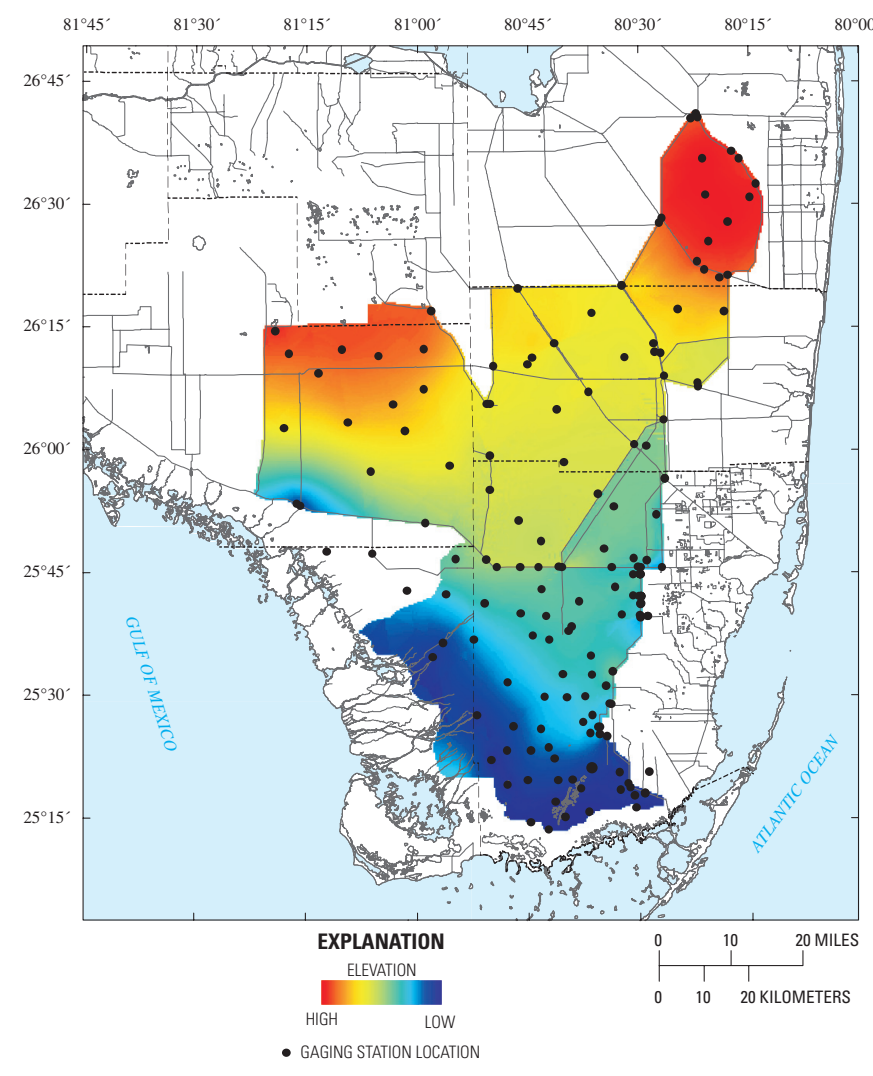

Figure 3. Example water-surface elevation from radial basis function multiquadric surfacing for a sample data.

\section{Ground-Elevation Model}

The EDEN domain was broken into a large number of equal-sized rectangles ("cells"), which in total, are referred to as the "grid." Characteristics of the grid, such as location of centroid, the representative area of the Everglades, elevation, and percentage of vegetation type, define the grid spatial parameters. The EDEN grid facilitates efficient GIS product development and distribution and allows for analysis of subsets of the grid or large-scale assessments at a system-wide level. The attribute information associated with grid cells can be expanded easily as new data are gathered or new information is derived.

Beginning with the first contoured surface created from the elevation data points in 1999 (http://sofia.usgs.gov), the ground-elevation model continues to be refined and used to improve water-depth estimates. The large number of elevation data allows for refinement of this model. The geostatistical technique of kriging was selected for the EDEN groundelevation model following extensive testing of multiple interpolation techniques. Kriging produced the lowest average error for validation of elevation points and provided useful diagnostic surfaces. To account for variations within subregions of the EDEN area, individual geostatistical models were created for each waterconservation area, ENP, and portions of BCNP. These individual models were combined to create a single, 400-meter resolution elevation model for the entire EDEN domain (fig. 2).

\section{Water-Surface Model}

A water-surface model was developed in GIS using the EDEN grid described above. The model interpolates measured water levels from the EDEN continuous monitoring network to ungaged locations. Different interpolation methods, such as inverse data weighting, spline, kriging, radial basis functions (RBF) with regularize spline, and RBF with multiquadric and local weighted regression, were tested on a subset of the assembled water-level dataset. The RBF with multiquadric regression, the basis for the EDEN water-surface model, provided the best results. The model produces a continuous water-surface elevation 
for any particular data within the period of record of the EDEN database. An example water-surface elevation from RBF multiquadric surfacing for a sample day is shown in figure 3.

\section{Internet Dissemination of EDEN Information}

The information from EDEN is readily available to scientists, engineers, and water-resource managers through a webpage that integrates the real-time monitoring data and GIS model results (fig. 4). The purpose of the website is to integrate EDEN monitoring and modeling data and provide "one-stop shopping" for data with a consistent data format and documentation. The EDEN website is accessed through an interactive map showing the location of gaging stations in the network, and provides "clickable" access to gage data on a near real-time basis (generally within 24 hours). Data from water-level gages are transmitted by way of radio or satellite telemetry to the operating agency's data servers. Data from BCNP, ENP, and SFWMD are then transferred to the USGS and entered into the USGS National Water Information System (NWIS) database. Once in NWIS, the data are available through the EDEN-NWIS web interface (http://fl.water. usgs.gov/eden) where the data can be accessed as graphs, tables, or downloadable files. The EDEN website also provides station information, such as station descriptions (including NAVD 88 correction values), measured ground elevation, and vegetation in the vicinity of the gaging station.

Ground-elevation and water-surface data as well as monitoring data for the Greater Everglades are available

\section{Figure 5. EDENapps} viewer screen. Shown is water depth for a user-specified area in the left-hand viewer, and water-level rate of change over a userspecific period of time for the same area in the right-hand viewer.



Figure 4. Transmission, transfer, storage, and access of data from the water-level data collected in the field to website access by users. NWIS is National Water Information System. EDEN is Everglades Depth Estimation Network.

of attributes for the EDEN grid are stored at the South Florida Information Access (SOFIA) website data servers (http://sofia. usgs.gov) for retrieval by way of a specially created, PC-based EDEN user interface (EDENapps) as illustrated in figure 5. EDENapps is a downloadable utility to the user's desktop computer and offers two main features that allow users the ability to: (1) communicate with the server to obtain water-surface data, and (2) view, analyze, and format these data for their use. Initially,

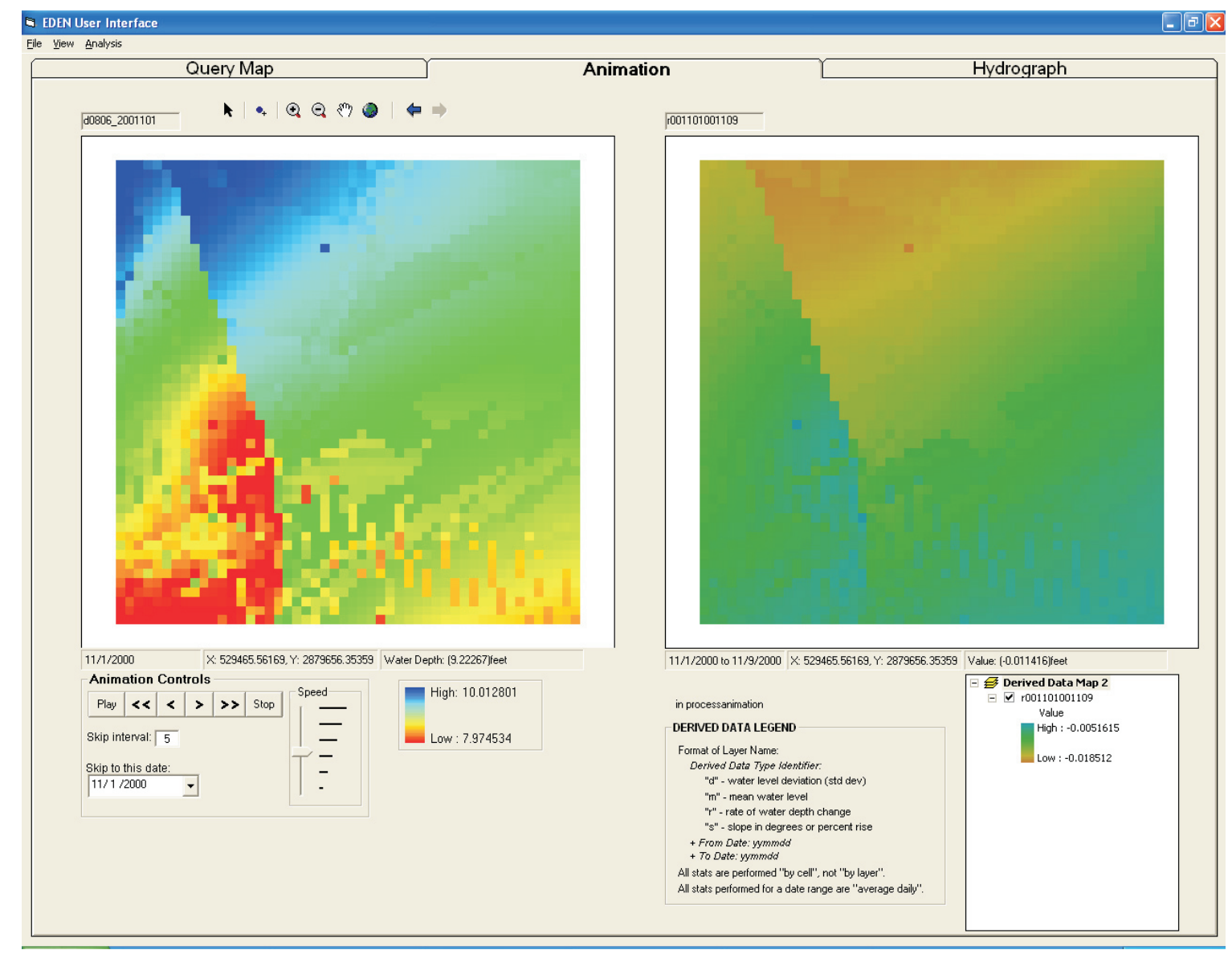


the interface is used to specify an area and dates of interest. These maps are collected from the SOFIA data storage server by the interface and displayed as an animation of water level over the specified period. The user then has options for examining the data in the interface, performing further analysis of the data within the interface, or exporting the data for external analysis and reports.

Analyses of the water-level maps currently available in EDENapps include cell-by-cell measures of variability, rates of change (rate of water-level subsidence or rise), number of dry events, and slope. Each of these derived products is saved as spatially referenced GIS maps that can be displayed within EDENapps. The interface has two side-by-side viewers to allow for pairwise comparisons of the map products. Individual cells also can be selected, and a hydrograph of water surface or water depth can be generated at those selected locations.

\section{Future Plans for EDEN}

Future plans for the EDEN network include finalizing the computation of water depths, refining ground elevations within EDEN 400-meter cells, integrating water depth and vegetation from other agencies, and extending the EDEN approach to coastal waters of the Everglades. Water depths are computed by subtracting the ground elevation (generated by the groundelevation model) from the water-surface elevation (generated by the water-surface model). The next version of EDENapp will have the utility to compute the average water depth for each EDEN cell.

Research has shown that relatively high-resolution data are needed to explicitly represent variations in the Everglades topography and vegetation that are important for landscape analysis and modeling (Jones, 2001). The EDEN project will provide a better representation of water depths if elevation variation within each 400-meter grid cell can be taken into account. Patterns of land cover obtained from existing GIS coverages of vegetation classifications may be the best available representation of variation in local elevation. Land-cover classifications from the Florida Gap Analysis Program (FLGAP) dataset (Florida Cooperative Fish and Wildlife Research Unit, 2005) and the SFWMD (Rutchey and others, 2005) are being input to analyze the relation among land cover and elevation. Accurate elevation data points will be combined with land-cover data to establish average differences in elevation as a function of land-cover type.
For these analyses, the land cover has been aggregated into six major communities:

(1) slough or open water, (2) wet prairie,

(3) ridge or sawgrass and emergent marsh,

(4) exotics and cattail, (5) upland, and

(6) other (mostly wetland shrub and wetland forested). Established relations will be used to proportion a grid cell into different depths as a function of modeled water surface and measured ground elevations. When the relation between vegetation communities and depth is finalized to better describe ground-elevation variations within a grid cell, water volume in each cell also will be generated. Other geospatial information, such as soils and water-quality data, will be integrated with hydrologic data from this and other projects on a public website.

The EDEN network provides a framework to integrate data collected by other agencies in a common quality-assured database. In addition to the real-time network, collaboration among agencies will provide the EDEN project with valuable historic vegetation and water- depth data. Scientists commonly collect water-depth and vegetation data when conducting biological field assessments. These data are then quality assured, properly compiled, and verified before being incorporated into the EDEN network to improve the waterdepth maps and ground-elevation data. About 60,000 observations of water depth with vegetation type are being compiled from the work of about 20 investigators covering the period from 1996 to 2004. Some data sites were sampled periodically, and other sites were sampled randomly. This is the first time these data have been compiled and analyzed as a collective set.

The EDEN network of analysis currently (2006) is for the freshwater (nontidal) portions of the Everglades. The EDEN network will be expanded to include the coastal (tidal) portions of the Everglades (fig. 2).

\section{Application for CERP}

EDEN's real-time data approach coupled with biological models, such as Across Trophic Level System Simulations (ATLSS) and Habitat Suitability Indices (HSIs), should help scientists: (1) evaluate how well the simulated relations that drive both biotic and abiotic models reflect and anticipate real-world events; and (2) examine trophic-level responses to hydrodynamic change. In summary, EDEN provides the hydrologically based data that can be used to assess biotic ecosystem responses to hydrologic change within the Greater Everglades.

\section{References}

Desmond, G.D., 2003, Measuring and mapping the topography of the Florida Everglades for Ecosystem Restoration: U.S. Geological Survey Fact Sheet 021-03.

Florida Cooperative Fish and Wildlife Research Unit, 2005, Florida GAP Analysis Project web page: Accessed at http://www.wec.ufl.edu/coop/GAP/.

Jones, J.W., 2001, Image and in situ data integration to derive sawgrass density information for surface-flow modeling in the Everglades: Remote Sensing and Hydrology 2000, IHAS 267, p. 507-512.

Rutchey, K., Vilchek, L., and Love, Matt, 2005, Development of a vegetation map for Water Conservation Area 3: West Palm Beach, South Florida Water Management District Technical Publication ERA \#421.

U.S. Army Corps of Engineers, 1999, Central and Southern Florida Project Comprehensive Review Study: Jacksonville, Florida, Final Integrated Feasibility Report and Programmatic Environmental Impact Statement.

For more information, please contact:

Project Team Leader:

Pamela A. Telis

U.S. Geological Survey

701 San Marco Blvd.

Jacksonville, FL 32207

email: patelis@usgs.gov

University of Florida,

Fort Lauderdale Project Team:

Dr. Leonard Pearlstine, Project Leader

Dr. Ikuko Fujisaki

Dr. Monica Palaseanu

Darcy Thomas

U.S. Geological Survey Project Team: Paul Conrads, Columbia, SC

Heather Henkel, St. Petersburg, FL

Aaron Higer (contractor, ETI

Professionals, Inc.), Ft. Lauderdale, FL

Dr. John W. Jones, Reston, VA

Eduardo Patino, Ft. Lauderdale, FL Roy Sonenshein, Ft. Lauderdale, FL Arturo Torres, Ft. Lauderdale, FL

http://sofia.usgs.gov/projects/eden/ 